\title{
DOS DANOS SOCIAIS
}

\section{SOCIAL DAMAGES}

\author{
Reis Friede ${ }^{1}$ \\ Luciano Aragão ${ }^{2}$
}

Resumo: Pretende-se com o presente estudo fomentar o debate doutrinário a respeito de uma nova espécie de dano, o dano social, modalidade que se diferencia do que a doutrina vem tratando como dano moral coletivo. $\mathrm{O}$ assunto será exposto, metodologicamente, em sessões, que versarão sobre a conceituação, a natureza jurídica, a classificação e a legitimidade para requerer o dano social e, ainda, a quantificação, a destinação da verba condenatória, a prova e o cabimento da aplicação da teoria da responsabilidade objetiva.

Palavras-chave: Danos sociais. Dignidade humana. Poder judiciário.

\begin{abstract}
The intention with the current study is to foment the doctrinaire debate concerning a new species of damage, the social damage, a modality that differs from what the doctrine is calling the collective moral damage. The issue will be exposed, methodologically, in sessions, which will deal about its concept, legal nature, the classification and the legitimacy to require the social damage, and, still, the quantification, the destination of the indemnity funds, the evidence and the suitability of the theory of strict liability.
\end{abstract}

Keywords: Social damages. Human dignity. Judicial power.

\section{INTRODUÇÃO}

Algumas decisões do Superior Tribunal de Justiça (STJ) têm reforçado a ideia da existência do dano social, ainda que distanciado da anterior e superada concepção de dano moral coletivo, conforme relatado pelo Ministro Luiz Fux no âmbito do REsp

1 Mestre e Doutor em Direito Público pela Universidade Federal do Rio de Janeiro (UFRJ). Pesquisador do Programa de Pós-Graduação em Desenvolvimento Local da UNISUAM. Desembargador Federal. Vice-Presidente do Tribunal Federal da $2^{a}$ Região.

2 Mestre em Direito, Professor da Graduação e Pós-Graduação em Direito e Advogado Empresarial. E-mail: rfriede@trf2.jus.br 
Dano moral coletivo. Necessária vinculação do dano moral à noção de dor, de sofrimento psíquico, de caráter individual. Incompatibilidade com a noção de transindividualidade (indeterminabilidade do sujeito passivo e indivisibilidade da ofensa e da reparação).

(STJ, REsp n ${ }^{\circ}$ 598.281/MG, Rel. Min. Luiz Fux).

As palavras do Ministro Luiz Fux fundamentam a noção de que o dano moral, em sua essência, é individual, personalíssimo e, portanto, contrário à ideia de coletividade, ao passo que o cerne do dano social (analisado no presente artigo) é justamente a sua natureza difusa, ou seja, relativo aquilo que atinge a coletividade.

A partir dessas noções, e com base no art. $1^{\circ}$, III, da Constituição Federal $(\mathrm{CF} / 1988)^{3}$, que estabelece a denominada cláusula geral de tutela da pessoa humana, desenvolver-se-á, no decorrer do presente estudo, a tese do cabimento dos danos sociais no direito brasileiro.

A Carta Magna de 1988 expressamente prevê que são objetivos da ordem social o bem-estar e a justiça social: "Art. 193. A ordem social tem como base o primado do trabalho, e como objetivo o bem-estar e a justiça sociais." (BRASIL, 1988).

Bem-estar social é o conjunto de fatores que uma sociedade ou grupo social precisa ter para viver bem e mais, sendo a qualidade de vida essencial, para que, individualmente, as pessoas possam usufruir de seus direitos e ter paz interior.

De acordo com Forton (1974, p. 38), o bem-estar deve ser visto como meta e instrumento do desenvolvimento, no qual o homem é o criador de seu próprio destino social e, como

3 Art. $1^{\circ} \mathrm{A}$ República Federativa do Brasil, formada pela união indissolúvel dos Estados e Municípios e do Distrito Federal, constitui-se em Estado Democrático de Direito e tem como fundamentos:

[...]

III - a dignidade da pessoa humana. (BRASIL, 1988). 
membro da sociedade, considerado não só como beneficiário do bem-estar, mas também como seu implementador. Dentro desta complexidade, pode-se inferir que o bem-estar é uma aspiração dos povos e dos indivíduos, que buscam a satisfação equitativa das necessidades em todos os setores, tais como o biológico, biofisiológico, material, intelectual, técnico, espiritual, moral, cultural e, por último, social.

Dessa forma, insere-se no conceito de bem-estar social tudo aquilo que se relaciona a uma qualidade de vida digna: meio ambiente equilibrado, emprego, política habitacional eficaz, acesso amplo e irrestrito à saúde, à Justiça e educação de qualidade, tempo para o lazer com a família e para a prática de esportes, política salarial digna etc.

Com efeito, toda vez que houver lesão ao bem-estar coletivo (interesse difuso tutelado pela ordem jurídico-constitucional) restará configurado o dano social, conceituado por Gonçalves (2003, p. 529) como: "Toda desvantagem que experimentamos em nossos bens jurídicos (patrimônio, corpo, vida, saúde, honra, crédito, bem estar, capacidade de aquisição etc)."

De forma não exaustiva, pode-se vislumbrar a existência de dano social nos casos que acarretam prejuízo aos usuários do sistema de telefonia móvel e de televisão a cabo; às comunidades residentes em locais próximos às barragens que se rompem; aos consumidores expostos à publicidade desleal; aos proprietários de apartamento em prédio com graves problemas estruturais; à economia popular por formação de cartel ou truste, entre outros.

Nesses casos, de acordo com o art. $5^{\circ}, \S 1^{\circ}$, da CF/1988, as normas definidoras dos direitos e garantias fundamentais possuem aplicação imediata. Embora a doutrina possa entender que o referido dispositivo constitucional possa ser classificado alternativamente, como norma de eficácia plena, de eficácia 
contida ou mesmo de eficácia limitada, importante destacar que não há no Texto Constitucional norma sem eficácia. Os dispositivos previstos na Lei Maior são, portanto, normas, e, nesse sentido, possuem normatividade e, assim, vinculam toda a sociedade.

Conforme preleciona Sarlet (2011, p. 255), "cada norma constitucional possui um mínimo de eficácia e aplicabilidade, dependente, por sua vez, de sua suficiente normatividade". Citando Garcia de Enterría, Sarlet (2011) reconhece o caráter vinculante reforçado e geral das normas constitucionais. Sustenta, ainda, que na Lei Fundamental não existem declarações (sejam elas oportunas ou inoportunas, felizes ou infelizes, precisas ou imprecisas) destituídas de normatividade, sendo certo que apenas o conteúdo concreto de cada norma poderá precisar, em cada caso, qual o alcance específico de sua carga eficacial. Assim, a função dos direitos fundamentais e sua estrutura jurídico-normativa na Constituição constituem o grau de eficácia e aplicabilidade dos direitos fundamentais.

Ainda segundo Sarlet (2011, p. 270-271), a melhor exegese a ser extraída a respeito da norma contida no art. $5^{\circ}, \S 1^{\circ}$, da $\mathrm{CF} / 1988$ é a que parte da premissa de que se trata de norma de cunho inequivocamente principiológico, considerando-a, portanto, uma espécie de mandado de otimização (ou maximização), isto é, impõe aos órgãos estatais a tarefa de conferir aos direitos fundamentais a maior eficácia possível, cujo alcance normativo, isto é, o quantum em aplicabilidade e eficácia, dependerá do exame da hipótese em concreto.

Em relação aos direitos fundamentais, à luz do significado outorgado ao art. $5^{\circ}, \S 1^{\circ}, \mathrm{CF} / 1988$, pode-se afirmar que aos poderes públicos incumbem a tarefa e o dever de extrair das normas que os consagram a maior eficácia possível, outorgando-lhes, nesse sentido, efeitos reforçados relativamente às demais normas constitucionais, uma vez que não há como 
desconsiderar a circunstância de que a presunção da aplicabilidade imediata e plena eficácia que milita em favor dos direitos fundamentais constituem, em verdade, um dos esteios de sua fundamentalidade formal no âmbito da Constituição, o que induz à afirmação de que, em certo sentido, os direitos e princípios fundamentais regem e governam a própria ordem constitucional.

\section{DANOS SOCIAIS}

A cláusula geral de tutela da pessoa humana, constante do art. $1^{\circ}$, III, da $\mathrm{CF} / 1988$, permite refletir a respeito da existência, no Direito brasileiro, de outras modalidades de dano, além daqueles já consagrados pela doutrina e jurisprudência pátria. Para tanto, é preciso entender, antes, o conceito filosófico de dignidade da pessoa humana, consoante a visão Kantiana: "O homem e, de uma maneira geral, todo o ser racional, existe como um fim em si mesmo, não simplesmente como meio para o uso arbitrário desta ou daquela vontade." (KANT, 1980, p. 134-135).

Prosseguindo, Kant reforça ainda mais a sua visão antropomórfica, afirmando que "em todas as suas ações, tanto nas que se dirigem a ele mesmo como nas que se dirigem a outros seres racionais, ele (o homem) tem sempre de ser considerado simultaneamente como um fim". (KANT, 1980, p. 134-135).

Para o filósofo, os seres cuja existência depende somente da natureza são denominados irracionais, sendo tratados como coisas, ao passo que os seres racionais ${ }^{4}$ são concebidos como pessoas, cuja natureza os distingue como fins em si mesmos, limitando, por conseguinte, todo o arbítrio. (KANT, 1980, p. 134-135).

4 É importante destacar que a concepção contemporânea sobre o tema substituiu a antiga noção de seres racionais para seres sencientes, ou seja,seres que possuem a consciência de sua própria existência. Tal conceito transcende o de racionalidade e, igualmente a limitada tradução anterior de "capacidade de sofrer e sentir prazer ou felicidade", para também abranger a autoconsciência, de forma diversa da ideia original de Charles Darwin. 
Maria Celina Moraes (2003, p. 80-81) argumenta que a concepção de dignidade de Kant tem como consequência a exigência de que o ser humano jamais possa ser visto ou usado como um meio para se atingir fins supostamente maiores do que o homem singular, mas sempre como o próprio fim. Em razão disso, toda a atividade estatal deve ser dirigida para o homem, tendo-o como finalidade a ser alcançada, de modo a possibilitar a realização máxima do valor da dignidade da pessoa humana. Aliás, para Kant, as coisas têm preço; as pessoas, dignidade.

\section{Diagrama 1: Bem-Estar Social e Justiça Social}

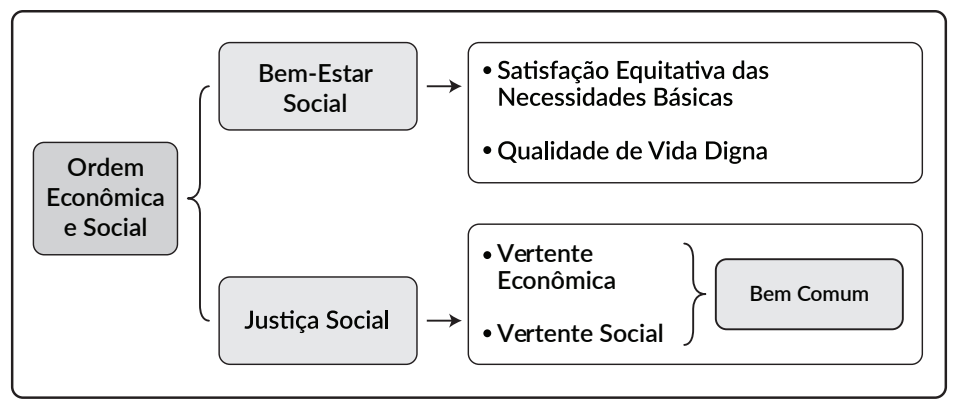

Mesmo não estando listado no Código Civil de 2002, o dever de indenizar por condutas socialmente reprováveis e geradoras de danos (imateriais e transindividuais) que piorem a qualidade de vida de certos grupos sociais decorre da cláusula geral de tutela da pessoa humana (art. 1º, III, da CF/1988).

Desse modo, o dano social não pode ser individualizado, posto que afeta a um grupo social determinado (pessoas residentes em um estado, município, bairro; pessoas que integram uma categoria profissional; pessoas que fazem parte de uma associação; pessoas portadoras de síndromes; consumidores) ou mesmo a um grupo social indeterminado.

Pode também o dano social ser relativo a toda população do país, a exemplo do que ocorre quando há queimadas na floresta 
amazônica, cujos efeitos nefastos podem sem experimentados pela população brasileira de um modo geral. Da mesma forma, a falta de investimentos adequados em infraestrutura afeta a qualidade de vida da sociedade como um todo, dando origem aos famosos apagões, ao racionamento de água. Igualmente acontece em decorrência do péssimo estado da malha rodoviária do país, problema que acaba por encarecer o preço do frete e, consequentemente, do produto final para o consumidor.

Outrossim, a infraestrutura deficiente pode ensejar os seguintes problemas, passíveis de configurar danos sociais: transportes rodoviário, ferroviário, marítimo, aéreo e fluvial deficientes; falta de fiscalização ambiental e seus consequentes danos; negligência na prestação dos serviços de segurança pública, de saúde e de educação; falta ou negligência na fiscalização dos serviços públicos delegados ao particular por meio de permissão, concessão ou autorização.

Com efeito, toda vez que o Estado ou o particular (pessoa física ou jurídica) agir (conduta comissiva) ou não agir (conduta omissiva), gerando danos à sociedade ou a um determinado grupo, restará configurado o denominado dano social.

\section{Diagrama 2: Dano Moral e Dano Social}

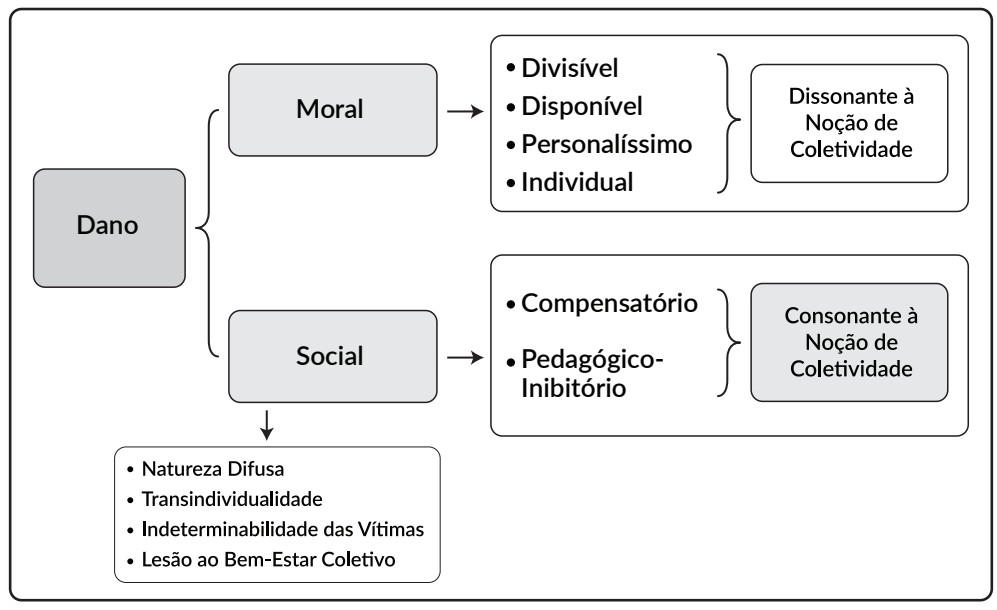


Desse modo, restando comprovada a falta de investimento em infraestrutura por longos anos (para que se possa justificar a negligência e não adentrarmos na seara da independência dos poderes ${ }^{5}$ ), e uma vez que tal fato tenha gerado prejuízo para a qualidade de vida da sociedade ou de um determinado grupo social, deve a União ser condenada a ressarcir os danos sociais, o mesmo ocorrendo com os Estados e Municípios, de acordo com a respectiva competência constitucional ${ }^{6}$; nesses casos, em particular por se tratar de ressarcimento (indiretamente) realizado pela própria sociedade, e em benefício dela mesma, a indenização limitar-se-á ao aspecto exclusivamente compensatório, jamais se revestindo de qualquer viés punitivo (ou inibitório-pedagógico) e, ainda assim, a grupos sociais determinados.

\section{De forma inequívoca, os particulares (na qualidade de}

5 Não adentraremos na questão da conveniência e oportunidade, atividade típica da Administração pública, que nos remeterá ao tema da separação dos Poderes e também ao tema da intervenção do Judiciário sempre que houver um hiato deixado pelos demais Poderes, principalmente na execução dos direitos fundamentais e das garantias sociais. A respeito do tema, Hermes Zanetti afirma: “[...] Por esta razão, as funções exercidas atualmente se dividem, na proporção da margem de disponibilidade da matéria, em funções de governo e funções de garantia. Uma vez que devemos reconhecer ao poder político e ao poder do mercado uma margem de discricionariedade/disponibilidade, que no primeiro corresponde à série de opções sobre políticas públicas e estratégias de desenvolvimento, que podem ser tomadas pelo legislador democraticamente eleito, e, no segundo, a autonomia da vontade, não podemos deixar de reconhecer que o poder político hoje é exercido igualmente pelos representantes eleitos no Executivo e no Legislativo, sendo que a própria atividade legiferante decorre desta legitimação popular, cada vez mais, já que o Executivo atua fortemente também neste campo. Assim, o que realmente diferencia os poderes é exercerem a sua legitimidade a partir da representação popular (Executivo e Legislativo) ou a partir da Constituição e das leis (Poder Judiciário e demais instituições de garantia dos direitos fundamentais, como as agências reguladoras e o Ministério Público). As funções de garantia estão assim diferenciadas das funções de governo, porque atuam para a conformação da margem do decidível, colocando-lhe limites e vínculos definidos pelos direitos fundamentais, a esfera do 'não decidível que' (direitos de liberdade) e o 'não decidível que não' (direitos sociais). A função de garantia, portanto, atua como função contra majoritária, assegurando os limites e vínculos decorrentes do nosso modelo constitucional garantista”. (ZANETI JR., 2013, p. 49-50).

6 Cabe, todavia, uma reflexão, se ao punir a União, os Estados e Municípios não estaríamos punindo também o próprio lesado, ou seja, a sociedade. Partindo do princípio que a União, os Estados e os Municípios constituem-se na própria sociedade organizada, estaríamos cobrando de nós mesmos pelos danos que sofremos. Porém, também é verdadeira a assertiva segundo a qual, no caso em questão, a sociedade como um todo estaria indenizando parte dela mesma ou a um grupo social determinado e, por esta razão, a restrição, inclusive quanto à natureza, apenas das duas competências. 
pessoa física ou jurídica) podem ser geradores de dano social, bastando, para tanto, que pratiquem atos socialmente reprováveis cujos efeitos sejam prejudiciais à qualidade de vida de toda a sociedade ou de determinado grupo social, tais como: atividades poluentes que afetem a flora, a fauna, os rios, os mares e as lagoas; atos de corrupção ativa; atos ofensivos aos direitos trabalhistas de determinadas categorias profissionais; atos contra a economia popular; formação de cartéis, trustes e prática de dumping; atos violadores dos direitos de determinados grupos de consumidores, bem como os que piorem a qualidade de vida de idosos, crianças e pessoas portadoras de deficiência. Cabe ressaltar que nos referidos casos os danos sociais poderão ostentar, simultaneamente, natureza compensatória e pedagógico-inibitória.

Para Trevizan e Silva (2007), havendo ofensa a interesse que extrapola o âmbito individual, o dever de indenizar, em sintonia com as diretrizes constitucionais do solidarismo social e da dignidade da pessoa humana, prestigiaria não apenas a vítima, mas também a coletividade, posto que caracterizada uma nova categoria de dano a ser indenizada: o dano social.

Assim, diante das figuras já existentes na doutrina e na jurisprudência, cumpre posicionar o dano social no ordenamento jurídico nacional, tarefa a ser empreendida a seguir.

\subsection{Conceito de dano social}

Em oportunidade pretérita lecionamos que natureza jurídica é a posição enciclopédica de um dado instituto no ordenamento jurídico. É a classificação a ser conferida a um termo ou a uma expressão no contexto complexo das diferentes classes jurídicas. É o que o instituto representa, considerando todas as suas implicações, inclusive de definição conceitual. Traduz, em última análise, sua organização e localização metodológico-pedagógica, bem como sua origem no contexto 
intrínseco de uma considerada disciplina científica (REIS FRIEDE, 2002, p. 434).

Maria Helena Diniz (2004), por sua vez, entende que natureza jurídica é a afinidade que um instituto tem em diversos pontos com uma grande categoria jurídica, podendo nela ser incluído a título classificatório. Trata-se, portanto, de buscar a essência de uma determinada figura com o fim de qualificá-la dentro do universo do Direito.

Nesse sentido, o dano social pode ser definido como aquele que é ocasionado por uma conduta (comissiva ou omissiva) socialmente reprovável, antijurídica ou não, praticada pelo Es$\operatorname{tado}^{7}$ ou por particular (pessoa física ou jurídica), cuja consequência é a diminuição da qualidade de vida da sociedade ou de determinado grupo social. Cabe destacar, nesta definição, que a causa do dano poder ser uma conduta socialmente reprovável, antijurídica ou não.

Entende-se por conduta socialmente reprovável a contrariedade do fato em relação ao sentimento comum de justiça; o comportamento que afronta o que o homem médio tem por justo, correto. Há, por conseguinte, uma lesividade social inserta na conduta, provocando um efetivo dano à coletividade, independente de o agente ter conhecimento de seu caráter da-

7 No que é pertinente ao Estado como causador do dano e legitimado passivo ad causam, destacamos alhures a dúvida que repousa acerca do tema. No caso, admitimos apenas a indenização (de natureza compensatória) a ser paga pelo Estado à parte da sociedade ou a um determinado grupo social. Não aceitamos, assim, o chamado dano punitivo, conforme corretamente vem se posicionando a jurisprudência majoritária do TRF/2 ${ }^{\mathrm{a}} \mathrm{Re}-$ gião. Neste sentido: TRF2 - Apelação Cível nº 0015560-71.2004.4.02.5101, Rel. Des. Fed. Reis Friede; TRF2 - Apelação Cível n 2005.51.01.016363-0, Rel. Des. Fed. Luiz Paulo da Silva Araújo Filho; TRF2 - Apelação Cível no 0624869-68.1984.4.02.5101, Rel. Juiz Federal Convocado José Eduardo Nobre Matta. Há na doutrina, porém, quem defenda o caráter principalmente punitivo do dano moral, figura conhecida como punitive damages ou exemplary damages, cuja aplicação é acentuada nos Estados Unidos. Contudo, conforme veremos adiante, seguimos a corrente doutrinária que não reconhece sua aplicação no Direito pátrio, tudo em razão da vedação contida no art. $5^{\circ}, \mathrm{XXXIX}$, da CF/1988. O fato dos julgados acima citados terem indeferido o pedido autoral de danos punitivos contra a União, não significa que autorizou a sua aplicação em outras situações. 
noso. Essa conceituação em muito se aproxima do conceito de ilicitude material proposto por Fernando Capez (2003), com a diferença de que o ato praticado, no caso do dano social, independe de afrontar ou não o texto legal, não se exigindo que o agente tenha conhecimento do caráter danoso de sua conduta, bastando, pois, a ocorrência do dano para que a mesma seja considerada ilícita à luz do que expressam os arts. $186^{8}$ e $187^{9}$ do Código Civil.

\subsection{Natureza jurídica do dano social}

Trata-se o dano social de um dano objetivo, transindividual e imaterial, podendo afetar a toda sociedade ou um determinado grupo social (homogêneo) em seu digno direito à qualidade de vida plena, seja em razão de um ato antijurídico (ou de conduta socialmente reprovável) praticado pelo Estado ou por particular (pessoa física ou jurídica), em detrimento de bens sociais imateriais que compõem o patrimônio social em específico lapso temporal. Trata-se, pois, de uma nova modalidade de dano não prevista no Código Civil de 2002, cuja previsão encontra-se, por construção hermenêutica, no art. $1^{\circ}$, III, da CF/1988.

\subsection{Modalidade de danos sociais}

A legislação brasileira prevê, como espécies de danos, os patrimoniais (danos emergentes e lucros cessantes) e os extrapatrimoniais (danos morais e danos estéticos), os quais repercutem na própria vítima ou em terceiros (dano por ricochet).

8 Art. 186. Aquele que, por ação ou omissão voluntária, negligência ou imprudência, violar direito e causar dano a outrem, ainda que exclusivamente moral, comete ato ilícito.

9 Art. 187. Também comete ato ilícito o titular de um direito que, ao exercê-lo, excede manifestamente os limites impostos pelo seu fim econômico ou social, pela boa-fé ou pelos bons costumes. 


\section{Diagrama 3: Modalidades de Dano no Direito Brasileiro" ${ }^{10}$}

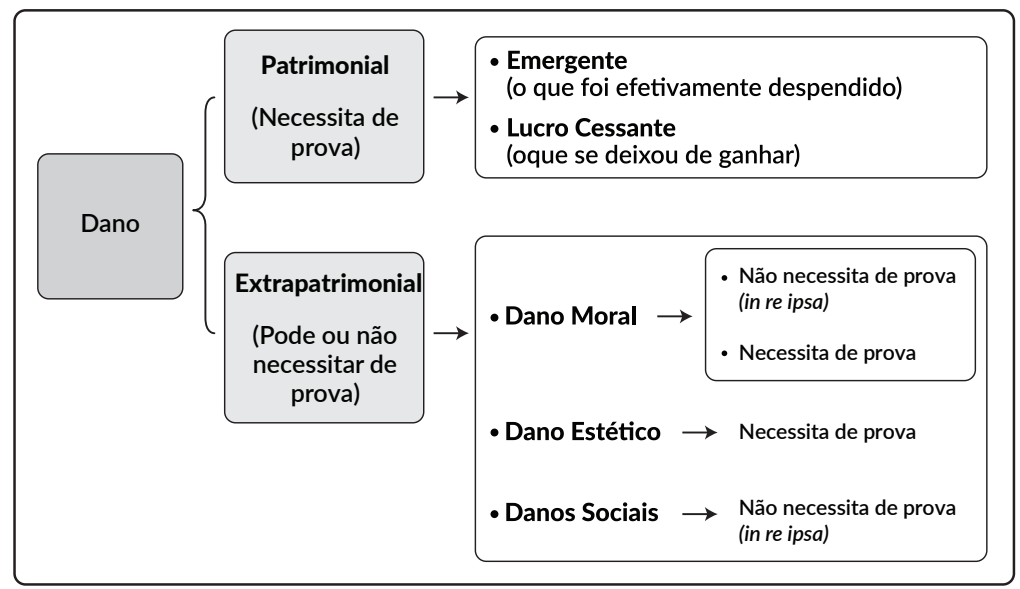

Tendo em vista a importância que o meio ambiente adquiriu para a vida humana nos últimos tempos, a doutrina tem discorrido muito sobre o dano ambiental, que na verdade configura uma espécie do gênero dano social, redundando no chamado dano social ambiental. Antunes Bessa (2000, p. 156) ensina que dano é o prejuízo (uma alteração negativa da situação jurídica, material ou moral) causado a alguém por um terceiro que se vê obrigado ao ressarcimento. O dano ambiental, afirma Antunes Bessa (2000), traduz-se num prejuízo ao meio ambiente.

Édis Milaré (2001, p. 422), por sua vez, expressa que “dano ambiental é a lesão aos recursos ambientais, com a consequente degradação, alteração adversa ou in pejus, do equilíbrio ecológico e da qualidade de vida". Nos termos da Lei n ${ }^{\circ} 6.938 / 81$, são recursos ambientais (art. $\left.3^{\circ}, \mathrm{V}\right)$ : a atmosfera, as águas interiores, superficiais e subterrâneas, os estuários, o mar territorial, o solo, o subsolo, os elementos da biosfera, a fauna e a flora.

10 O Dano Social está sendo considerado uma construção doutrinária no presente artigo. Diante de seu caráter inovador, ainda prescinde de debate doutrinário mais amplo e, consequentemente, de aplicação pelos Tribunais para que seja considerada uma forma de dano válida e indenizável no Direito Brasileiro. Contudo, o Superior Tribunal de Justiça - STJ já admitiu sua existência nos julgados Reclamação n ${ }^{\circ}$ 12.062/GO; 16.447/GO;15.464/GO, entre outros e também na V Jornada de Direito Civil do CJF que originou o Enunciado 456. 
Dessa forma, uma vez que repercute diretamente na sociedade, eventual lesão aos referidos recursos ambientais configurará um dano social ambiental.

Outrossim, quando houver ofensa a um direito meta-individual pertencente a toda sociedade, com repercussão na dignidade humana dos trabalhadores e nos valores sociais do trabalho, restará caracterizado o dano social trabalhista. Exemplo clássico do que ora se afirma é o chamado dumping social, figura que Trierweiler (2005) define como sendo uma prática realizada por certos Estados, consistente em pagar salários muito baixos e oferecer precárias condições de trabalho, reduzindo-se severamente os gastos com mão de obra, tudo com o intuito de possibilitar que seus produtos tenham preços inferiores se comparados com os praticados no mercado internacional ou, então, que o baixo custo da mão de obra dos trabalhadores locais seja atraente à instalação de novas empresas.

Mina Kawai (2010, p. 3) explica que o dumping social também ocorre quando os preços baixos dos bens resultam do fato de as empresas produtoras estarem instaladas em países onde não são cumpridos os direitos humanos mais elementares, bem como os direitos dos trabalhadores internacionalmente reconhecidos, permitindo, assim, que os custos sociais da mão de obra sejam extremamente baixos, acarretando, por conseguinte, uma queda artificial dos preços produzidos em condições laborais ilegítimas e atentatórias à dignidade humana.

O dumping social ocorre, por exemplo, na China, nas Filipinas e no SriLanka, países nos quais se nota uma sobrevalorização do progresso econômico em detrimento do bem-estar social e da dignidade do trabalhador.

No Brasil já ficou convencionada a existência do dano social trabalhista, mas com nomenclatura equivocada (dano moral coletivo), conforme anteriormente mencionado. 


\section{ENUNCIADO 04 ${ }^{11}$ :}

DUMPING SOCIAL. DANO À SOCIEDADE. INDENIZAÇÃO SUPLEMENTAR. As agressões reincidentes e inescusáveis aos direitos trabalhistas geram um dano à sociedade, pois com tal prática desconsidera-se, propositalmente, a estrutura do Estado social e do próprio modelo capitalista com a obtenção de vantagem indevida perante a concorrência. A prática, portanto, reflete o conhecido "dumping social", motivando a necessária reação do Judiciário trabalhista para corrigi-la. O dano à sociedade configura ato ilícito, por exercício abusivo do direito, já que extrapola limites econômicos e sociais, nos exatos termos dos arts. 186, 187 e 927 do Código Civil. Encontra-se no art. 404, parágrafo único do Código Civil, o fundamento de ordem positiva para impingir ao agressor contumaz uma indenização suplementar, como, aliás, já previam os artigos 652, “d”, e 832, § 1, da CLT.

\section{Gustavo Abrantes (2011) aduz que nas reclamações traba-} lhistas em que for constatada uma ação deliberadamente praticada no sentido de desrespeitar a ordem jurídica trabalhista, deve o magistrado proferir condenação que vise à reparação específica pertinente ao dano social perpetrado, ainda que fixada ex officio, de modo a proteger a coletividade, a ordem jurídica e a paz social. ${ }^{12}$

\section{Há, ainda, os que defendem que as empresas que frequente-}

11 Enunciado aprovado na $1^{a}$ Jornada de Direito Material e Processual na Justiça do Trabalho. Revista - LTr Legislação do Trabalho: Publicação Mensal de Legislação, Doutrina e Jurisprudência, São Paulo, v. 71, n. 12, p. 1500-1507, dez. 2007.

12 Não se trata, no entendimento de Gustavo Abrantes, de jurisdição sem a devida provocação, pois a decisão do juiz se dará por adição supletiva ao pedido de condenação em danos extrapatrimoniais, conforme expresso no parágrafo único do art. 404 do Código Civil e, neste caso, sem qualquer caráter compensatório, apenas inibitório-pedagógico (que não se confunde com o punitivo). $\mathrm{O}$ caráter inibitório em questão é estabelecido com um fim específica e limitadamente pedagógico (e não punitivo), por ser este último incompatível com o art. $5^{\circ}, \mathrm{XXXIX,} \mathrm{da} \mathrm{CF/1988.} \mathrm{Ademais,} \mathrm{o} \mathrm{entendimento} \mathrm{segundo} \mathrm{o}$ qual 'É nula, por configurar julgamento extra petita, a decisão que condena a parte ré, de ofício, em ação individual, ao pagamento de indenização a título de danos sociais em favor de terceiro estranho à lide" (STJ, Reclamações no 12.062/GO, n ${ }^{\circ}$ 16.447/GO, $\mathrm{n}^{\circ} 16.443 / \mathrm{GO}, \mathrm{n}^{\mathrm{o}} 15.494 / \mathrm{GO}, \mathrm{n}^{\circ} 14.856 / \mathrm{GO}, 16.441 / \mathrm{GO}$ e $\left.\mathrm{n}^{\circ} 13.201 / \mathrm{GO}\right)$ baseou-se na impossibilidade de condenação, em ação individual e sem pedido expresso, em danos sociais compensatórios. Conforme analisaremos adiante, a doutrina tem entendido que os legitimados para figurar no polo ativo da demanda em que são postulados danos sociais são os que figuram no art. $5^{\circ}$ da Lei $n^{\circ} 7.347 / 85$, porquanto são demandas coletivas. 
mente figuram como reclamadas na Justiça do Trabalho devem ser condenadas a ressarcir danos individuais e também danos sociais trabalhistas, justamente por terem optado pela demanda em detrimento do cumprimento da legislação laboral. ${ }^{13}$

O mesmo raciocínio deve ser aplicado em se tratando de dano social consumerista, administrativo, econômico ou dano social sem outra especificação (dano oriundo de ofensas aos direitos das crianças, dos adolescentes, dos idosos, das pessoas com deficiênciaetc.).

Como exemplo de danos sociais consumeristas, podem ser citados os casos de propaganda enganosa, venda de produtos impróprios para o consumo, aumento indevido de mensalidades de planos de saúde, cobrança de juros extorsivos pelas instituições financeiras, etc.

Danos sociais administrativos, por sua vez, são os danos transindividuais causados por ação ou omissão da administração pública direta, suas autarquias e fundações, pois é seu dever primar pelo atendimento ágil e eficiente, de modo a não prejudicar interesses da sociedade. Por oportuno, deve ser banida da cultura nacional a ideia de que ser mal atendido faz parte dos aborrecimentos triviais do cidadão, principalmente

13 Neste aspecto, resta oportuno destacar que expressiva parcela da doutrina entende incabível a condenação por danos sociais compensatórios em ação individual. De igual forma, há grande discordância, também, de se condenar, nas ações coletivas ou populares, em danos sociais compensatórios sem que exista pedido expresso na exordial, por afrontar os arts. $2^{\circ}, 128$ e 460, todos do CPC. Contudo, parece-nos perfeitamente cabível a condenação ex officio por danos sociais pedagógicos inibitórios suplementares, em ações coletivas, individuais e populares, desde que destinados a um fundo do Judiciário, do Ministério Público ou da Defensoria Pública, caso figurem estas últimas instituições no polo ativo da demanda coletiva, em razão de sua função constitucional garantidora dos direitos fundamentais. Neste sentido, Bedaque afirma que, à luz dos arts. 128, 459 e 460 do CPC, está o juiz objetivamente limitado aos elementos da demanda deduzidos pelo autor na inicial. O pedido formulado e os motivos deduzidos pelo autor representam o âmbito de atuação do julgador, que não poderá conceder mais ou coisa diversa da pretendida, nem apresentar razões diferentes das elencadas. Se o fizer, configurar-se-á o fenômeno do julgamento ultra ou extra petita, o que poderá implicar em nulidade da sentença. Tais regras decorrem diretamente do princípio da demanda e da inércia da jurisdição. Na medida em que se admitisse ao juiz conceder ao autor mais do que fora pedido, ou por razões diversas das deduzidas na inicial, estar-se-ia possibilitando a tutela jurisdicional de ofício. Tudo o que excedesse os limites objetivos da demanda implicaria atuação sem provocação. (BEDAQUE, 2005, p. 390). 
quando tal comportamento advém dos entes administrativos. O cidadão não pode ser compelido a suportar as consequências da má organização, do abuso e da falta de eficiência daqueles que devem, com boa vontade, solicitude e cortesia, atender ao público. ${ }^{14}$

Os danos sociais econômicos podem ser exemplificados pela formação de cartéis, prática de truste e dumping, ações lesivas à economia popular, ao mercado financeiro, de valores e de capitais etc.

\section{Diagrama 4: Modalidades de Dano Social}

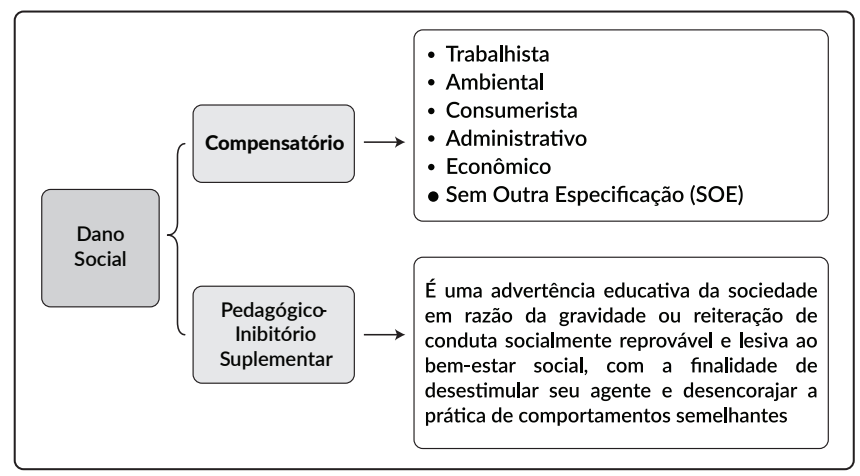

\subsection{Classificação dos danos sociais}

Quanto à classificação, os danos sociais podem ser: extrapatrimonial, extrínseco, certo, compensatório, pedagógico-inibitório, indireto e previsto. Vejamos cada um deles.

Dano extrapatrimonial: dano que ocasiona uma perda na qualidade de vida da sociedade ou de determinado grupo social, atingindo, portanto, um bem imaterial. Embora, neste caso, o dano causado possa ter expressão pecuniária para efeito de sua recomposição, tal situação será objeto de pedido de danos emergentes ou até mesmo de lucros cessantes quando do

14 STJ, Primeira Turma, REsp n ${ }^{\circ}$ 608.918-RS, Rel. Min. José Delgado, julgamento em 29 maio 2004, publicado no DOU de 21 jun. 2004. 
ajuizamento da ação indenizatória cabível.

Dano extrínseco: ocorre quando o dano se estende a outras situações distintas daquela que restou lesada. Por exemplo, o dano social ambiental não repercute apenas no bioma lesado, mas, sim, atinge toda população que dele depende (qualidade do ar, da água, dos peixes etc.) de forma direta e indireta.

Dano certo: nesta espécie, em razão do dano ser passível de ressarcimento, a condenação trará efetividade à decisão judicial.

Dano compensatório: quando a conduta (ação ou omissão) geradora do dano é definitiva, isto é, a anulação daquela não enseja o desaparecimento deste.

Dano pedagógico-inibitório:aquele que deve ser aplicado como forma de advertência educativa e suplementar à condenação compensatória.

Dano indireto: ocorre quando a pessoa que postula o ressarcimento devido for diferente da vítima do dano, muito embora seja seu representante (não confundir com procurador).

Dano previsto: no caso, o dano é previsível, ou seja, é possível, em certas circunstâncias, antever os efeitos deletérios da ação ou omissão.

\subsection{A Prova na persecução do dano social}

Muito embora esteja consagrado no Direito brasileiro que o dano deva ser efetivamente comprovado, tal diretriz aplica-se apenas às modalidades de danos patrimoniais (danos emergentes e lucros cessantes) ou, ainda, a uma espécie de dano extrapatrimonial (o dano estético), tendo em vista que este depende de perícia para se apurar a sua extensão.

O dano social, por sua vez, é presumido (in re ipsa), decorrendo da força do próprio ato. Assim, há dano social quando o direito à qualidade de vida digna e bem-estar social é lesa- 
do por uma conduta socialmente reprovável ou antijurídica. Vale dizer, o dano social é presumido em razão da dimensão do próprio fato em si, sendo mesmo impossível não reconhecer que o prejuízo social efetivamente aconteceu. Com efeito, basta apenas a demonstração da ocorrência do fato para que se possa concluir pela existência do dano, não necessitando ser extensamente provado. Por exemplo, não há necessidade de se provar que toda a sociedade do município do Rio de Janeiro sofre danos sociais decorrentes da poluição da Baía da Guanabara, bem como que os moradores da Barra da Tijuca sofrem os mesmos efeitos em virtude da poluição do complexo lagunar existente na região. E, ainda, que parte da população dos Estados de Minas Gerais e do Espírito Santo sofre danos sociais decorrentes do rompimento da Barreira da Mineradora Samarco, desastre ambiental de proporções inimagináveis ocorrido em 5 de novembro de 2015.

\subsection{A Forma de responsabilização}

O Código Civil de 2002 adotou, como regra, a teoria da responsabilidade subjetiva, conclusão que se extrai da análise conjunta dos arts. 186 e 187. A responsabilidade civil por dano social, por sua vez, é de natureza objetiva (art. 927, parágrafo único, do Código Civil).

$\mathrm{O}$ art. 186 do Código Civil preceitua que aquele que, por ação ou omissão voluntária, negligência ou imprudência, violar direito e causar dano a outrem, ainda que exclusivamente moral, comete ato ilícito.

Por sua vez, o art. 187 afirma que comete ato ilícito o titular de um direito que, ao exercê-lo, excede manifestamente os limites impostos pelo seu fim econômico ou social, pela boa-fé ou pelos bons costumes.

Por fim, o art. 927, parágrafo único, do mesmo Estatuto 
expressa que haverá obrigação de reparar o dano, independentemente de culpa, nos casos especificados em lei, ou quando a atividade normalmente desenvolvida pelo autor do dano implicar, por sua natureza, risco para os direitos de outrem.

Nota-se, no último caso, a consagração do risco criado ou risco proveito e, assim, a responsabilidade passa a ser objetiva em razão do exercício de determinada atividade empresarial e/ ou nos casos especificados na legislação, tais como: Decreto $\mathrm{n}^{\mathrm{o}} 2.681 / 12$ (responsabilidade das estradas de ferro por danos causados aos proprietários marginais); Lei ${ }^{\circ}$ 5.316/67; Decreto $n^{\circ}$ 61.784/67; Lei n ${ }^{\circ} 8.213 / 91$ (legislação de acidente de traba1ho); Lei $\mathrm{n}^{\circ}$ 6.194/74 e Lei $\mathrm{n}^{\circ}$ 8.441/92 (seguro obrigatório de acidentes de veículos, cabendo à seguradora pagar o valor previsto, independente de culpa do motorista); Lei ${ }^{\circ}$ 6.938/81 (referente aos danos causados ao meio ambiente); Lei n ${ }^{\circ} 8.078 / 90$ (Código de Defesa do Consumidor); art. 37, § 6º da CF/1988 (responsabilidade das pessoas jurídicas de direito público e de direito privado concessionárias de serviço público).

\subsection{A legitimidade ativa Ad Causam}

Entende-se que os legitimados para a propositura de ação civil pública (legitimidade ativa ad causam) também o são para, em nome da sociedade ou de determinado grupo social, pleitear danos sociais.

Por conseguinte, na forma do art. $5^{\circ}$ da Lei ${ }^{0} 7.347 / 85$, que disciplina a ação civil pública de responsabilidade por danos causados ao meio ambiente, ao consumidor, a bens e direitos de valor artístico, estético, histórico, turístico e paisagístico, figuram como legitimados:o Ministério Público;a Defensoria Pública; a União, os Estados, o Distrito Federal e os Municípios; a autarquia, empresa pública, fundação ou sociedade de economia mista; a associação que, concomitantemente:a) esteja constituída há pelo menos 1 (um) ano nos termos da lei civil;b) inclua, 
entre suas finalidades institucionais, a proteção ao patrimônio público e social, ao meio ambiente, ao consumidor, à ordem econômica, à livre concorrência, aos direitos de grupos raciais, étnicos ou religiosos ou ao patrimônio artístico, estético, histórico, turístico e paisagístico e, também, para parte da doutrina, ainda que de forma controvertida, as agências reguladoras.

Igualmente, nos termos do art. $3^{\circ}$ da Lei $n^{\circ} 7.853 / 89$, que, entre outras providências, dispõe sobre o apoio às pessoas portadoras de deficiência, sua integração social, bem como institui a tutela jurisdicional de interesses coletivos ou difusos dessas pessoas e disciplina a atuação do Ministério Público, as ações civis públicas destinadas à proteção de interesses coletivos ou difusos das pessoas portadoras de deficiência poderão ser propostas pelo Ministério Público, pela União, pelos Estados, Municípios e Distrito Federal; por associação constituída, nos termos da lei civil, há mais de 1 (um) ano, autarquia, empresa pública, fundação ou sociedade de economia mista que inclua, entre suas finalidades institucionais, a proteção das pessoas portadoras de deficiência.

Nesse elenco de legitimados para pleitear danos sociais, particularmente no âmbito trabalhista, devem ser incluídos os sindicatos, as federações e as confederações sindicais.

Por ferir o art. $6^{\circ}$ do Código de Processo Civil, segundo o qual ninguém poderá pleitear, em nome próprio, direito alheio, salvo quando autorizado por lei, cabe registrar o entendimento que inadmite pedido de indenização por danos sociais compensatórios nas ações individuais. Não obstante o que ora se afirma, poderá o juiz, em razão do grau de ofensa ao bem-estar social, ou mesmo em virtude da contumácia do réu, e com o objetivo de conferir proteção aos direitos insculpidos no art. $6^{\circ}$ da $\mathrm{CF} / 1988^{15}$, condenar (ex officio) a parte ré em danos sociais

15 Nesse caso, o dano social pedagógico-inibitório perde o caráter de suplementariedade ao dano social compensatório. Contudo, o juiz está legitimado a condenar ex officio em razão 
pedagógico-inibitórios.

Nesse sentido, cabe trazer à colação o teor do Enunciado $\mathrm{n}^{\circ}$ 456, da V Jornada de Direito Civil/Conselho da Justiça Federal, segundo o qual a expressão "dano", prevista no art. 944 do Código Civil, abrange não apenas os danos individuais (materiais ou imateriais), mas também os danos sociais, difusos, coletivos e individuais homogêneos, a serem reclamados pelos legitimados para propor ações coletivas.

Salvo melhor juízo, entendemos que o referido Enunciado, no caso em questão, refere-se aos danos sociais compensatórios, e não aos sociais inibitórios. Assim, ainda que o autor da ação individual tenha formulado pedido de fixação de dano social compensatório, forçoso reconhecer que o mesmo carece de legitimidade para pleitear, em nome próprio, direito inerente à coletividade.

Contudo, há hipótese em que tal pedido de condenação por danos sociais compensatórios pode ser feito cumulativamente na ação popular, em particular quando restar evidenciado que o ato que se deseja anular gerou, além de um dano ao patrimônio público, um dano social, podendo também os danos sociais pedagógico-inibitórios suplementares serem pedidos de forma supletiva aos danos sociais compensatórios, conforme se infere do art. 404, parágrafo único, do Código Civil.

Tal entendimento decorre do fato de a ação popular ter por objetivo a defesa do patrimônio público, do erário, da moralidade administrativa e do meio ambiente, ou seja, o autor representa a sociedade como um todo, agindo no intuito de salvaguardar o interesse público. Dessa forma, está o juiz autorizado a requisitar provas às entidades públicas, mesmo que ex officio, conforme já decidiu, inclusive, o Superior Tribunal de Justiça:

de sua função jurisdicional constitucional de garantidor dos direitos e garantias fundamentais, uma vez que o momento atual requer um Judiciário proativo para inibir a ineficiência das prestações dos serviços básicos e garantir a efetividade dos direitos sociais. 
ADMINISTRATIVO E PROCESSUAL CIVIL. AÇÃO POPULAR. DESVIO DE REPASSE DE VERBAS PÚBLICAS. PREFEITURA MUNICIPAL. PETIÇÃO INICIAL DEFICIENTE PELA FALTA DE DOCUMENTOS VINCULADOS A ENTIDADES PÚBLICAS. INÉPCIA DA EXORDIAL. AFASTAMENTO.

I-A discussão em debate foi decidida pelo Tribunal de origem, considerando-se inepta a petição inicial de ação popular, sob o argumento de que o autor não teria trazido os documentos essenciais para o deslinde da causa e que a juntada de tais elementos, no transcurso processual, somente se justificaria quando negado o fornecimento de certidões e informações, por parte do Poder Público.

II-A falta de inclusão dos documentos indispensáveis ao processo na exordial, que dependem de autorização de entidades públicas, não impõe a inépcia da peça vestibular, porquanto o juiz tem a faculdade de requisitá-los aos órgãos, durante a instrução do processo, quando houver requerimento para tanto, no teor do art. $7^{\circ}$, inciso I, alínea "b", da Lei no 4.717/65.

III-Tratando-se de ação popular, em que se defende o patrimônio público, o erário, a moralidade administrativa e o meio-ambiente, onde o autor está representando a sociedade como um todo, no intuito de salvaguardar o interesse público, está o juiz autorizado a requisitar provas às entidades públicas, máxime na hipótese dos autos, na qual existe requisição expressa nesse sentido.

IV - "Uma vez postulada, pelo autor, de forma expressa, a requisição de documento essencial à propositura da ação, não se há falar em inépcia da inicial, por ausência da documentação necessária” (REsp no 152.925/SP, Relator para acórdão Ministro DEMÓCRITO REINALDO, DJ de 13/10/1998, p. 00021).

V-Recurso especial provido, afastando a extinção do processo, por inépcia da inicial, e determinando a remessa dos autos ao Tribunal de origem, para que este se manifeste acerca do mérito da causa.

(STJ, Primeira Turma, REsp n ${ }^{\circ}$ 439.180/SP, Rel. Min. Francisco Falcão, julgamento em 21 set. 2004, DJ 3 nov. 2004, p. 37) 


\subsection{A quantificação do dano social}

No tocante ao tema, cumpre destacar que os danos sociais devem ser fixados de acordo com a extensão do dano, devendo o magistrado, ao empreender tal tarefa, utilizar-se dos critérios da proporcionalidade e da razoabilidade, levando em conta, ainda, a capacidade econômica do agente causador, de modo a assegurar a efetividade do comando judicial, exegese equitativa que se extrai do art. 944 do Código Civil.

Com efeito, da mesma forma que a indenização a ser fixada não poderá ser módica diante da capacidade econômica do agente, pois se o for estará premiando aquele que praticou o ilícito, também não poderá redundar em enriquecimento sem causa para quem a recebe (no caso específico dos danos sociais compensatórios).

Como cediço, reveste-se de importância o aspecto didático-pedagógico da condenação, cabendo ao magistrado sopesar todos esses critérios no momento da fixação do quantum indenizatório.

No que diz respeito à indenização por danos sociais, os tipos compensatório e pedagógico-inibitório suplementar são da máxima importância.

A distinção entre o dano compensatório e o reparatório reside no fato deste último traduzir uma espécie de "danos materiais futuros". Apesar de sua existência doutrinária ser questionável, o dano reparatório está presente na aplicação do Direito concreto, pois se trata do valor que irá ser despendido pelo réu para recompor o bem jurídico lesado pela sua conduta, conduzindo, assim, ao status quo ante.

Dessa forma, os danos compensatórios (ou remuneratórios) são instrumentos de equidade e podem ser aplicados pelo juiz para equilibrar os prejuízos ocorridos na qualidade de vida 
e no bem-estar social. Afinal, instrumentos de equidade servem para aproximar a decisão o mais possível do senso de justiça em cada caso. Assim, os danos sociais compensatórios servem para remunerar o dano sofrido na esfera extrapatrimonial como forma, no caso em destaque, de se indenizar pela piora provocada na qualidade de vida e no bem-estar da sociedade.

Os danos sociais pedagógico-inibitórios suplementares possuem finalidade não punitiva, pois, do contrário, seriam incompatíveis com o sistema jurídico pátrio, conforme expresso no art. 5', XXXIX, da CRFB/88. O seu caráter, portanto, é meramente disciplinador, educativo e pedagógico.

Cabe destacar, ademais, que os danos sociais pedagógico-inibitóriossuplementares não são aplicáveis apenas diante da contumácia do causador, mas também em razão de sua gravidade, da conduta demasiadamente reprovável, insultuosa e ultrajante à consciência social e coletiva, uma vez que independem de culpa ou dolo do agente, incidindo tão somente em razão da gravidade e extensão do dano, configurando, assim, uma advertência da sociedade em relação à referida conduta, buscando impedir sua reiteração.

Tal advertência restou evidenciada em artigo elaborado por Edson Ubaldo (2009), Desembargador do Tribunal de Justiça do Estado de Santa Catarina, sendo perfeitamente aplicável, por analogia, aos danos sociais:

Os maiores responsáveis pelos sofrimentos infligidos às pessoas, em especial os grandes conglomerados financeiros e comerciais, passaram a disseminar a ideia de que a busca pela reparação de danos morais se transformara em ‘indústria' de ganhos fáceis.

Ubaldo (2009) afirma que essa "suposta verdade contaminou parte da magistratura", argumentando, ainda, que tal aspecto "não só reforçou o argumento dos juízes mais conservadores, que por razões ideológicas, inclusive de fundo religioso, nunca 
viram com bons olhos o novo instituto jurídico (refere-se o autor ao dano moral), como também serviu de freio aos mais liberais, cujas sentenças passaram a ser reformadas para diminuir os valores fixados."

Nota-se nitidamente que o mencionado magistrado desaprova a posição que insiste em afirmar que o "o dano moral se transformou em indústria". Para ele, este é argumento é falso, tendo em vista que o número de pleitos mostra exatamente o contrário:

$\mathrm{O}$ consumidor brasileiro, antes desamparado e agora protegido pelo CDC, tomou consciência de seus direitos, ao invés de "queixar-se ao bispo", como antes lhe sugeriam bancos e lojas. Agora se queixa ao juiz; b) os responsáveis por produtos e serviços ainda não se convenceram de que os tempos mudaram e continuam a violar descaradamente os direitos da cidadania. Portanto, o que de fato existe é a "indústria" do desrespeito, a busca do lucro fácil, a sensação de que vale a pena continuar enganando o povo, porque o percentual dos reclamantes é ínfimo, os processos são lentos e o resultado final, ainda que favorável ao consumidor, sai muito mais barato do que investir na melhoria dos produtos e dos serviços. ${ }^{16}$

Cabe registrar, ainda, que a verba condenatória imposta a título de danos sociais pedagógico-inibitórios suplementares não deve ser direcionada ao grupo social (ou ao fundo que ele indicar) que teve seu patrimônio imaterial lesado, visto que, para isso, se destinam os danos sociais compensatórios. Os danos sociais pedagógico-inibitórios suplementares, que, como visto alhures, possuem caráter de sublime advertência educativa, devem ser destinados, por esta razão, a fundos de órgãos com função constitucional garantidores dos direitos fundamentais e sociais, como, por exemplo, o Poder Judiciário. Isto porque, além de caracterizar bis in idem, ou seja, duas indenizações pelo mesmo fato, tal situação ensejaria ainda um nítido

16 O Judiciário - Jornal mensal da Associação dos Magistrados Catarinenses, ano IV, $\mathrm{n}$. 38, jun./2009. Disponível em: <www.amc.org.br>. Acesso em: 20 set. 2015. 
enriquecimento sem causa por parte do autor, figura vedada pelo Direito brasileiro. A natureza suplementar da condenação por danos sociais pedagógico-inibitórios encontra amparo no art. 404, parágrafo único, do Código Civil.

\section{Diagrama 5: Características dos Danos Sociais}

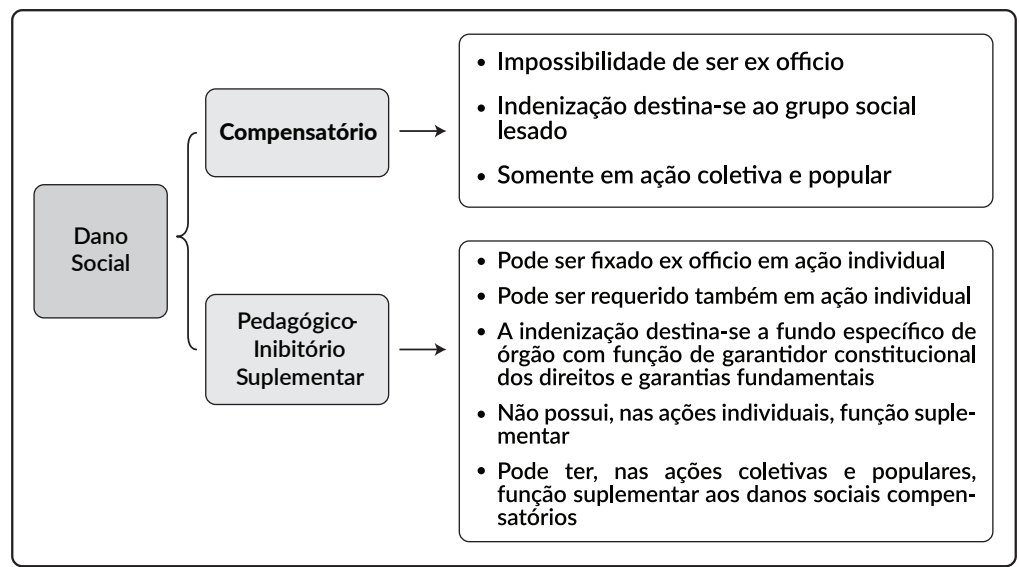

\subsection{A destinação da verba oriunda da condenação por dano social}

Quanto à destinação, os recursos oriundos da condenação por danos sociais devem ser divididos em duas etapas, a saber:

a) A verba condenatória por danos sociais compensatórios pertence à sociedade ou a um determinado grupo social em razão da piora acarretada na qualidade de vida e no bem-estar social. Por isso, tal verba deve necessariamente ficar retida em conta judicial, cabendo ao autor da ação enviar ao juízo um projeto de melhoria da qualidade de vida lesada, objetivando restabelecer ao máximo a ambiência social vivida antes do dano se efetivar. Tal projeto será homologado pelo juízo depois de ouvido o Ministério Público, devendo, essencialmente, conter um cronograma dos pagamentos, de modo que o dinheiro depositado na citada conta possa ser liberado de acordo com o 
cronograma das despesas.Somente após o autor da ação comprovar a concretização do projeto e o uso da quantia depositada (na conta judicial) é que o processo deverá ser julgado extinto.

b) Já a verba condenatória por danos sociais pedagógico-inibitórios suplementares, em razão de seu caráter de advertência educativo-social, deve ser destinada não ao autor da ação, conforme já se tratou, mas a um fundo de órgão dotado de função constitucional de garantidor dos direitos fundamentais ${ }^{17}$, tais como, por exemplo, o Poder Judiciário e o Ministério Público, ficando ao prudente arbítrio do juiz a quantificação e a destinação ao fundo pertinente.

Como cediço, a responsabilidade do Poder Judiciário como protagonista na defesa dos direitos fundamentais sociais ainda está em fase de consolidação, razão pela qual é fundamental despertar os membros da Magistratura para a importância da função judicante na defesa de tais direitos. A propósito, José Faria (1994) salienta que os direitos humanos foram originariamente constituídos como uma forma de proteção contra os abusos e arbítrios praticados pelo Estado, concretizando-se somente por intermédio desse mesmo Estado. Tem razão José Faria ao fazer tal afirmação, mormente porque os direitos sociais surgiram juridicamente como prerrogativas dos indivíduos menos favorecidos, sob a forma normativa de obrigações do Executivo, demandando, assim, uma intervenção ativa e continuada por parte dos poderes públicos. Ainda em consonância com José Faria, a característica básica dos direitos so-

17 Nesse particular, entendemos que não há conflito com o fundo expresso nos arts. $13 \mathrm{e}$ 20 da Lei $n^{\circ} 7.347 / 85$, regulamentada pelo Decreto $n^{0} 1.306 / 94$, vez que a condenação a título de danos sociais inibitórios pedagógicos suplementares, se destinados ao Poder Judiciário, também reverterá para a sociedade na forma de garantia dos direitos fundamentais, retirando de seus ombros parte dos custos com a máquina judicial, que hoje estão na ordem de $1,3 \%$ do PIB. KRELL (2002, p. 70) afirma que na medida em que é menor o nível de organização e atuação da sociedade civil para participar e influenciar na formação da vontade política, aumenta a responsabilidade dos integrantes do Poder Judiciário na concretização e no cumprimento das normas constitucionais, especialmente as que possuem uma alta carga valorativa e ideológica. 
ciais está no fato de que,

[...] forjados numa linha oposta ao paradigma kantiano de uma justiça universal, foram formulados dirigindo-se menos aos indivíduos tomados isoladamente como cidadãos livres e anônimos e mais na perspectiva dos grupos, comunidades, corporações e classes a que pertencem. ${ }^{18}$ Ao contrário da maioria dos direitos individuais tradicionais, cuja proteção exige apenas que o Estado jamais permita sua violação, os direitos sociais não podem simplesmente ser “atribuídos" aos cidadãos; cada vez mais elevados à condição de direitos constitucionais, os direitos sociais requerem do Estado um amplo rol de políticas públicas dirigidas a segmentos específicos da sociedade - políticas essas que têm por objetivo fundamentar esses direitos e atender às expectativas por eles geradas com sua positivação. (FARIA, 1994, p. 54).

Com efeito, tais direitos, para a sua efetivação, pressupõem a substituição da "repressão" pela "promoção" e da sanção penal (ou punitiva) pela de natureza premial (FARIA, 1994, p. 54). Logo, os direitos sociais não configuram um direito de igualdade, baseado em regras de julgamento que implicam um tratamento uniforme, mas um "direito das preferências e das desigualdades, ou seja, um direito discriminatório com propósitos compensatórios; um direito descontínuo, pragmático e por vezes até mesmo contraditório, quase sempre dependente da sorte de determinados casos concretos" (FARIA, 1994, p. 54):

Trata-se de um tipo específico de direitos, cujas práticas judiciais pressupõem a legitimidade processual e o reconhecimento da personalidade jurídica dos grupos e representações coletivas; consagrando um novo padrão de racionalidade, de natureza essencialmente material ou substantiva, que colide com os limites estritos da racionalidade formal

18 A teoria kantiana, a nosso sentir, não é a da valorização do homem (de forma isolada) como objetivo das ações de Estado em detrimento da coletividade. Máxima vênia, a teoria kantiana, na verdade, expressa que o bem-estar do homem deve ser o fim que as políticas do ente estatal devem perseguir, e não ser usado como meio para que o Estado atinja outros fins (desenvolvimento econômico). Em sua teoria, Kant valoriza o ser humano e não a coisa (os bens) como fim a ser perseguido pelas ações estatais. 
das leis e dos códigos típicos do Estado liberal clássico, os direitos sociais são politicamente editados com o objetivo de socializar riscos, neutralizar perdas e atenuar diferenças, mediante tratamentos diversificados por parte das múltiplas instâncias do setor público. (FARIA, 1994, p. 54).

Nos burocratizados tribunais brasileiros, cujos integrantes parecem acreditar que os conflitos podem ser solucionados pelo simples apego a certas formas e/ou pela ritualização de atos, ainda segundo José Faria (1994), os direitos humanos e os direitos sociais estão obrigando a magistratura a refletir um pouco mais sobre suas funções sociais.

Eduardo Bittar (2005), também com mestria, destaca o papel do Judiciário na quadra atual, afirmando que a ele "cumpre um determinante papel na construção, proteção e garantia da efetividade dos direitos humanos dentro da tradicional estrutura tripartite de poderes herdada da modernidade" (BITTAR, 2005, p. 306).

Assevera o autor, ainda, que uma sociedade na qual a cidadania se realiza é aquela que tem amplo acesso aos direitos, o que "significa afirmar que estes direitos são realizados ou respeitados, e também que, quando são violados, possuem proteção e garantia jurisdicional". Como se vê, segundo a reflexão de Bittar, o papel do Judiciário é ponto central nas discussões sobre a temática dos direitos humanos e sociais.

\section{CONCLUSÃO}

Conforme discutido durante o presente artigo, conclui-se que há uma impossibilidade concreta e doutrinária de condenação por danos morais coletivos. Claro está que os verdadeiros danos coletivos homogêneos oriundos da piora acarretada na qualidade de vida e no bem-estar social são os denominados danos sociais, presentes, em nosso sistema jurídico, por força 
do disposto art. $1^{\circ}$, III, da CF/1988, sob a modalidade de dano extrapatrimonial, imaterial, transindividual e objetivo.

O dano social é um tipo de dano que repercurte na diminuição da qualidade de vida da sociedade ou de determinado grupo social, podendo ser decorrente de uma conduta perpetrada pelo Estado ou por um particular.

Quanto à sua posição no campo do Direito, trata-se o dano social de um dano objetivo, transindividual e imaterial, que afeta $a$ sociedade como um todo ou determinado grupo social, alterando para pior sua qualidade de vida em razão de conduta socialmente reprovável ou antijurídica praticada pelo Estado ou por um particular.

A legitimidade para pleitear danos sociais é inerente às instituições listadasno art. $5^{\circ}$ da Lei $n^{\circ} 7.347 / 85$, além dos sindicatos, das federações e confederações, dos representantes dos empregados e empregadores e também do cidadão, neste último caso por meio de pedido cumulado em ação popular ou em ação individual (apenas na modalidade de dano pedagógico-inibitório).

A forma de responsabilização do causador do dano é objetiva (in re ipsa), podendo serrequerido por meio de ação coletiva ou via ação popular, cuja quantificação deverá obedecer aos critérios da proporcionalidade, razoabilidade e capacidade econômica do agente.

Os recursos oriundos da condenação por danos sociais compensatórios devem ser aplicados em projetos de melhoria da qualidade de vida da sociedade ou do grupo social lesado. Por sua vez, os recursos da condenação por danos sociais pedagógico-inibitórios suplementares devem ser destinados a um fundo criado por órgãos com função constitucional de garantidor dos direitos fundamentais sociais.

Espera-se, dessa forma, ter contribuído para a discussão 
doutrinária a respeito da instituição deste novo tipo de dano, o dano social, no direito brasileiro.

\section{REFERÊNCIAS}

ANTUNES, Paulo Bessa. Direito ambiental.4. ed. rev. ampl. e atual. Rio de Janeiro: Lumen Juris, 2000.

BEDAQUE, José Roberto dos Santos. Código de processo civil interpretado. Antônio Carlos Marcato, coordenador. 2. ed. São Paulo: Atlas, 2005.

BITTAR, Eduardo Carlos Bianca. O direito na pós-modernidade. Rio de Janeiro: Forense Universitária, 2005.

CAPEZ, Fernando. Curso de direito penal.5. ed. São Paulo: Saraiva, 2003.

CARVAS, Luiz Gustavo Abrantes. Desmistificando o dumping social. Teresina:Jus Navigandi, 2011.

DINIZ, Maria Helena. Curso de direito civil brasileiro: teoria geral do direito civil. 21. ed. São Paulo: Saraiva, 2004.

ENNECERUS \& LEHMANN. Derecho de obligaciones. v. 1, § 10, Barcelona, 1935, apudGONÇALVES, Carlos Roberto. Responsabilidade Civil. São Paulo: Saraiva, 2003.

FARIA, José Eduardo. Os desafios do Judiciário.Revista USP. São Paulo, n. 21, pp. 47-57: Coordenadoria de Comunicação Social (CCS)/USP, 1994.

FORTON, Rozendo Escalanate. Indicadores do bem-estar social: seu conteúdo e sua atualização. Debates Sociais, v. 10, n. 18, Rio de Janeiro, 1974.

FRIEDE, Reis. Aspectos fundamentais das medidas liminares. 5. ed. Rio de Janeiro: Forense Universitária, 2002.

KANT, Immanuel. Fundamentação da metafísica dos costumes.In: Os Pensadores Kant (II), Trad. Paulo Quintela. São Paulo: Abril Cultural, 1980, pp. 134-135 apudBIZELLI. Rafael Ferreira. Disponível em: <http://www.publicadireito.com.br/artigos/?cod $=68$ c694de94e6c110 $>$. Acesso em: 30 ago. 2015.

KAWAY, Mina. Dumping social: as normas de trabalho e sua relação com o comércio internacional. Instituto Declatra, Florianópolis, 2010.

KRELL, Andreas Joachim. Direitos sociais e controle judicial no Brasil e na Alemanha: os (des)caminhos de um direito constitucional comparado. Porto Alegre: Sergio Antonio Fabris Editor, 2002.

MILARÉ, Édis. Direito do ambiente. Doutrina - prática - jurisprudência - glossário.2. ed. rev. ampl. e atual. São Paulo: RT, 2001.

MORAES, Maria Celina Bodin de. Danos à pessoa humana: uma leitura civil-constitucional dos danos morais. Rio de Janeiro: Renovar, 2003, pp. 80-81 apud BIZELLI,Rafael Ferreira. Disponível em: <http://www.publicadireito.com.br/artigos/?cod=68c694de94e6c110>. Acesso em: 30 ago. 2015. 
SARLET, Ingo Wolfgang. A eficácia dos direitos fundamentais:uma teoria geral dos direitos fundamentais na perspectiva constitucional.10. ed. Porto Alegre: Livraria do Advogado, 2011.

TREVIZAN, Thaita Campos; SILVA, Vitor Borges da. O dano social como reflexo das novas tendências da responsabilidade civil.Revista Científica-Faculdade Pio XII, Campo Grande, 2007.

TRIERWEILER, Gustavo F. As relações de trabalho, o dumping e a crise econômica. Revista IOB Trabalhista e Previdenciária, v. 21, n. 242, São Paulo, 2005.

ZANETI JR., Hermes. A teoria da separação de poderes e o estado democrático constitucional:Funções de governo e funções de garantia. In:GRINOVER, Ada Pellegrini. O controle jurisdicional de políticas públicas. Coordenadores Ada Pellegrini Grinover, kazuo Watanabe. 2. ed. Rio de Janeiro: Forense, 2013.

Artigo recebido em 14/04/2016

Artigo aprovado em 08/06/2016 